\title{
UJI REAKSI PASAR TERHADAP PENGUMUMAN \\ DIVIDEN TUNAI PERIODE 2003-2004 \\ (Studi Komparasi Antara Perusahaan yang mengumumkan Dividen Naik dan \\ Perusahaan yang mengumumkan Dividen Turun di Bursa Efek Jakarta)
}

\author{
Erwin Budianto \\ Erwinbudianto2@gmail.com \\ Pengajar Universitas Swadaya Gunung Jati Cirebon
}

\begin{abstract}
ABSTRAK
Penelitian ini akan menguji kandungan informasi pengumuman dividen tunai naik dan turun, perbedaan rata-rata abnormal return antara perusahaan yang mengumumkan dividen tunai naik dengan perusahaan yang mengumumkan dividen tunai turun serta menguji reaksi pasar antara perusahaan yang mengumumkan dividen tunai naik dan turun yang dilihat dari nilai rata-rata abnormal returnnya. Populasi yang digunakan adalah perusahaan yang mengumumkan dividen tunai yang listed dan terdaftar di Bursa Efek Jakarta selama periode 2003-2004. Sedangkan sampel penelitian sebanyak 64 perusahaan, terdiri dari 40 perusahaan yang mengumumkan dividen tunai naik dan 24 perusahaan yang mengumumkan dividen tunai turun. Hasil penelitian menunjukkan bahwa pada perusahaan yang mengumumkan kenaikan dividen, pasar tidak bereaksi. Hal ini mengindikasikan bahwa tidak ada kandungan informasi pada pengumuman kenaikan dividen tunai. Sedangkan pada perusahaan yang mengumumkan penurunan dividen tunai, pasar bereaksi pada hari t-2 sebelum pengumuman dividen tunai turun. Pengujian terhadap perbedaan rata-rata abnormal return sebelum dan sesudah pengumuman dividen tunai naik dan turun, menunjukkan tidak ada perbedaan antara rata-rata abnormal return sebelum dan sesudah pengumuman dividen tunai naik dan turun. Dari hasil uji perbedaan reaksi pasar antara perusahaan yang mengumumkan dividen tunai naik dengan perusahaan yang mengumumkan dividen tunai turun, berdasarkan analisis yang dilakukan terhadap nilai rata-rata abnormal return, diperoleh hasil tidak ada perbedaan reaksi pasar antara perusahaan yang mengumumkan dividen tunai naik dan turun. Dari penelitian tersebut dapat disimpulkan bahwa pengumuman dividen tunai tidak mengandung informasi kecuali untuk perusahaan yang mengumumkan dividen tunai turun.
\end{abstract}

Kata Kunci : Pengumuman Dividen, reaksi pasar, abnormal return 


\begin{abstract}
This research examines information content of cash dividends announcements increase and decrease. The difference of average abnormal return between companies announcing of cash dividend and also the market reaction toward the increase and decrease of cash dividend announcement seen from value of it's average abnormal return. The population used is companies announcing cash dividends and listed in Jakarta Stock Exchange for 2003-2004 period. The sample is 64 companies consisting 40 companies announcing the increase of cash dividends and 24 companies announcing the decrease of cash dividends. The result shows that those companies announcing the increase of cash dividends, the market is not reactive. It indicate that there is no content information on the announcement of cash dividends increase. Mean while those companies announcing the decrease of cashdividends, the market is reactive, especially in the $\mathrm{t}-2$ before announcement of cash dividends. The test of the difference of average abnormal return before and after on the announcement of the increase and the decreas of cash dividends, show that there is no difference between average abnormal return before and after announcement of increase and decrease cash dividends. The result of different test market reaction between companies announcing the increase and the decrease of cash dividends, based on the analyze toward average abnormal returnis derived that there is no difference in market reaction between companies announcement the increase and the decrease of cash dividends. Of the research, it can be concluded that the cash dividends announcement. Does doesn't have information content except for those companies announcing the decrease of cash dividends.
\end{abstract}

Key words: Dividends Announcement, Market Reaction, Abnormal Return

\section{PENDAHULUAN}

Pasar modal merupakan pertemuan antara pihak yang memiliki kelebihan dana dengan pihak yang membutuhkan dana dengan cara memperjual belikan sekuritas. Pasar modal bertujuan untuk menunjang pelaksanaan pembangunan nasional dalam rangka meningkatkan kesejahteraan dan kemakmuran rakyat.

Pasar modal mempunyai peranan strategis sebagai salah satu sumber pembiayaan bagi dunia usaha termasuk usaha menengah dan kecil, sedangkan disisi lain pasar modal merupakan wahana investasi bagi pemilik modal baik pemodal besar, menengah maupun kecil. (Harianto, 2001).

Informasi tentang naik turunnya dividen tunai yang dibagikan perusahaan merupakan salah satu informasi yang dipandang cukup penting bagi para investor, karena dalam informasi tersebut mengandung muatan informasi (information content)yang berkenaan dengan prospek keuntungan yang akan diperoleh suatu perusahaandimasa yang akan datang. Hal ini disebabkan, dalam kondisi dimana investor dihadapkan pada ketidakpastian yang tinggi terhadap hasil kegiatan investasinya, maka informasi naik turunnya dividen tunai dapat dijadikan indikator untuk memperkirakan prospek keuntungan perusahaan dimasa yang akan datang, hal ini disebabkan karena manajemen (perusahaan) pada umumnya tidak akan mengambil resiko dengan membayar dividen yang tinggi pada suatu waktu tertentu bila menurut perkiraan mereka perusahaan tidak mampu mempertahankannya di masa yang akan datang. Oleh karena itu, adanya kenaikan dividen dapat diperkirakan sebagai tanda 
optimis pihak manajemen (perusahaan) sehubungan dengan keuntungan perusahaan di masa yang akan datang. Demikian pula penurunan dividen dapat diperkirakan sebagai penurunan keuntungan di masa yang akan datang. ( Prasetiono, 2000).

Lintner (1956) dalam Setiawan \& Hartono (2003) Menyatakan bahwa kenaikan dividen merupakan sinyal dari manajemen mengenai kepercayaan mereka bahwa laba akan mengalami peningkatan secara permanen di masa depan. Pemberian sinyal ini membutuhkan biaya, maka hanya perusahaan yang berprospek yang mampu menanggungnya. Apabila sinyal tersebut diberikan oleh perusahaan yang tidak berprospek, maka perusahaan tersebut tidak akan mampu menanggung biaya signalling, dan akan mengalami kesulitan likuiditas yang pada akhirnya akan merugikan investor. Oleh karena itu, investor harus mampu membedakan antara perusahaan yang berprospek dan tidak supaya tidak dibodohi oleh emiten. Apabila kenaikan dividen tersebut berasal dari 17perusahaan yang berprospek ekonomis, maka pasar akan bereaksi positif. Akan tetapi, apabila perusahaan yang mengumumkan kenaikan dividen tersebut perusahaan yang tidak berprospek, maka pasar akan bereaksi secara negatif. Apabila investor hanya memperhitungkan kenaikan dividen saja tanpa memperhatikan apakah sinyal tersebut validatau tidak, sehingga merespon secara positif pengumuman dividen yang diberikan oleh perusahaan yang berprospek atau tidak, maka investor tersebut merupakan investor yang bodoh (naive).

Studi mengenai kandungan informasi bertujuan untuk melihat kandungan dari suatu peristiwa yang terjadi. Apabila peristiwa yang terjadi membawa informasi, maka dapat dikatakan bahwa peristiwa tersebut mempunyai kandungan informasi. Sebaliknya apabila suatu peristiwa tidak membawa informasi, maka dapat dikatakan bahwa peristiwa tersebut tidak mempunyai kandungan informasi. (Hartono, 2005).

Studi mengenai kandungan informasi merupakan bagian dari studi peristiwa (event study). Studi peristiwa adalah studi yang mempelajari reaksi pasar terhadap suatu peristiwa (event).Event studi dapat digunakan untuk menguji kandungan informasi(information content) suatu pengumuman dan dapat dilanjutkan untuk menguji efisiensi pasar bentuk setengah kuat, (Hartono, 2005).

Miller dan Rorke (1985) dalam Setiawan \& Sitti (2005) menyatakan bahwa dividend signaling theorymerupakan teori yang menyatakan bahwa pengumuman dividen merupakan sinyal yang diberikan oleh manajer 18 mengenai keyakinan mereka tentang perkembangan perusahaan dimasa depan. Manajer sebagai pihak dalam tentu mempunyai akses yang lebih baik mengenai kemampuan perusahaan dan mereka dapat menyampaikan keyakinannya mengenai perkembangan perusahaan kepada investor melalui pengumuman dividen. Gelb (1999) membuktikan bahwa dividen merupakan suatu sinyal yang baik untuk menyampaikan maksud perusahaan kepada investor. Pengumuman dividen dapat digunakan investor untuk memperkecil asimetri dengan manajer sehingga pengumuman dividen merupakan informasi yang berguna untuk pengambilan keputusan. Oleh karena itu, pengumuman dividen mempunyai kandungan informasi yang berguna.

Setiawan dan Hartono (2003) membuktikan bahwa investor di BEJ bereaksi terhadap pengumuman dividen secara cepat, sehingga abnormal return yang dinikmati oleh investor hanya pada saat pengumuman. Petit (1972) melakukan pengujian terhadap sampel yang terdiri dari 625 perusahaan selama periode januari 1964 - juni 1968. Hasil yang didapat ada reaksi pasar yang signifikan 
terutama pada bulan pengumuman dividen, artinya pengumuman

mempunyai kandungan informasi yang substansial bagi investor.

Sujoko (1999) melakukan pengujian terhadap pengumuman dividen meningkat selama periode 1994 - 1996 dengan menggunakan model market adjusted, mean adjusteddan market model untuk menghitung abnormal return.Hasil yang didapat adalah menunjukkan selama 3 hari sehari sebelum pengumuman, hari pengumuman dan sehari setelah pengumuman dividen meningkat terdapat reaksi pasar yang positif signifikan. Artinya bahwa 19pengumuman dividen mempunyai kandungan informasi yang berguna bagi investor.

Setiawan \& Hartono (2003) melakukan pengujian terhadap pengumuman dividen meningkat periode 1992 - 1996 dengan sampel 132 perusahaan. Hasil menunjukkan bahwa pasar bereaksi terhadap pengumumandividen meningkat pada saat pengumuman. Artinya bahwa pengumuman dividen mempunyai kandungan informasi yang berguna bagi investor.

Gonedes (19780 melakukan pengujian terhadap dividen, laba dan extraordinary item yang berasal dari 258 perusahaan periode april 1952 - maret 1972. Hasil yang didapat adalah bahwa pengumuman dividen tidak mempunyai kandungan informasi yang berguna bagi investor.

Brooks (1996) melakukan pengujian terhadap pengumuamn dividen untuk tahun 1988 serta menguji perubahan asimetris informasi, relative spreaddan volume perdagangan untuk melihat perubahan antara periode sebelum dan sesudah pengumuman. Hasil yang didapat adalah bahwa asimetri informasi yang terjadi tidak mengalami perubahan yang signifikan begitu juga relatif spread dan volume perdagangan. Artinya bahwa pengumuman dividen tidak mempunyai kandungan informasi yang berguna bagi investor.

Penelitian ini dilakukan karena terdapat beberapa research gap dari penelitian terdahulu yang berkaitan dengan kandungan informasi dari pengumuman dividen. Gonedes (1978) dan Brooks (1996) hasil dari penelitiannya menunjukkan bahwa pengumuman dividen tidak mempunyai kandungan informasi. Sedangkan Petit (1972), Aharony dan Swary (1980), Firth (1994), Benartzi et al (1997), Mikhail et al (1999)hasil dari penelitian mereka ternyata menunjukkan bahwa pengumuman dividen mempunyai kandungan informasi yang berguna bagi investor untuk mengambil keputusan investasi.

Beberapa peneliti di Indonesia juga menunjukkan hasil yang tidak konsisten berkaitan dengan kandungan informasi dari pengumuman dividen. Amsari (1993), Soetjipto (1997), dan Rahardjo (2000) mereka tidak berhasil membuktikan kandungan informasi pengumuman dividen. Sedangkan yang dapat berhasil membuktikan kandungan informasi pengumuman dividen adalah penelitian yang dilakukan oleh Sujoko (1999), Suparmono (2000), Setiawan \& Hartono (2003) dan Yusnitasari (2003).

Penelitian ini akan menguji apakah pengumuman dividen tunai naik dan turun mempunyai kandungan informasi atau tidak, apakah rata-rata abnormal return sebelum dan sesudah pengumuman dividen tunai naik dan turun mempunyai perbedaan yang signifikan serta apakah reaksi pasar antara perusahaan yang mengumumumkan dividen tunai naik dan dividen tunai turun mempunyai perbedaan yang signifikan untuk periode 2003-2004.

Berikut Hipotesis yang digunakan dalam penelitian ini.

$\mathrm{H} 1$ : Adanya kandungan informasi pada pengumuman dividen tunai naik dan turun.

$\mathrm{H} 2$ : Adanya perbedaan yang signifikan antara rata-rata abnormal return sebelum dan sesudah pengumuman dividen tunai naik dan turun. 
H3 : Adanya perbedaan reaksi yang signifikan antara perusahaan yang melakukan pengumuman dividen tunai naik dan perusahaan yang melakukan pengumuman dividen tunai turun.

\section{METODE PENELITIAN}

Populasi dalam penelitian ini adalah seluruh perusahaan yang melakukan pengumuman dividen dan terdaftar di Bursa Efek Jakarta untuk periode 2003-2004. Data yang diperoleh dari Jakarta Stock Exchange Corner
UNIKA, terdapat 163 Perusahaan yang melakukan pengumuman dividen pada periode tahun tersebut. Sedangkan penentuan sampel dipilih dengan menggunakan metode purposive sampling dengan kriteria sebagai berikut :

a. Perusahaan mengumumkan dividen tunai tahun 2003-2004.

b. Perusahaan yang selama periode pengamatan sahamnya aktif diperdagangkan.

Tabel berikut ini merupakan tabel penentuan sampel berdasarkan kriteria yang telah dijelaskan diatas.

Tabel 3.1

\section{Penentuan Sampel}

\begin{tabular}{|c|l|c|}
\hline Nomor & \multicolumn{1}{|c|}{ Kriteria Seleksi } & $\begin{array}{c}\text { Jumlah Emiten } \\
\text { yang lolos }\end{array}$ \\
\hline 1 & $\begin{array}{l}\text { Populasi (Seluruh emiten yang melakukan pengumuman dividen } \\
\text { tunaiyang listed dan terdaftar di BEJ tahun 2003-2004) }\end{array}$ & 163 Perusahaan \\
\hline 2 & $\begin{array}{l}\text { Perusahaan tidak melakukan pengumuman lain selain } \\
\text { pengumuman dividen tunai }\end{array}$ & 163 Perusahaan \\
\hline 3 & Perusahaan melakukan pengumuman dividen tunai naik dan turun & 64 Perusahaan \\
\hline 4 & $\begin{array}{l}\text { Perusahaan yang selama periode pengamatan sahamnya aktif } \\
\text { diperdagangkan }\end{array}$ & 64 Perusahaan \\
\hline
\end{tabular}

Sumber: Data Sekunderyang diolah, 2006

Berdasarkan teknik sampling diatas, diperoleh sampel sebanyak 64 perurahaan. Sampel dalam penelitian ini dikelompokkan menjadi du bagian, yaitu perusahaan yang melakukan pengumuman dividen tunai naik sebanyak 40 perusahaan dan perusahaan yang melakukan pengumuman dividen tunai turun sebanyak 24 perusahaan.

\section{Metoda Analisis Data}

1. Event Study

Dalam teknik analisis data ini, tahaptahap penelitian yang dilakukan adalah:

a. Mengidentifikasi event day, yaitu tanggal pengumuman dividen dari masing-masing perusahaan. Untuk mempermudah event daytersebut diidentifikasi sebagai hari ke-0. b. Menentukan event windowatau periode dimana reaksi harga terhadap peristiwa pengumuman dividen akan diukur. Event window yang digunakan adalah lima hari sebelum peristiwa (preevent),satu hari pada saat peristiwa (event day),dan lima hari setelah peristiwa (post day)

Dengan demikian, untuk sepenuhnya mengukur reaksi harga, titik awal pengukuran reaksi dimulai pada hari ke -5 (lima hari sebelum peristiwa), ini dimaksudkan untuk mengetahui ada tidaknya kebocoran informasi mengenai peristiwa pengumuman dividen, sedangkan event daydisini tanggal 49 pengumuman dividen, post dayyang 
digunakan lima hari sesudahnya, ini dimaksudkan untuk menyeimbangkan pre-eventyang ada serta untuk mengetahui reaksi pasar mengenai peristiwa pengumuman dividen. Penggunaan periode jendela 11 hari dimana 5 hari sebelum, pada saat peristiwa, dan 5 hari sesudahnya adalah untuk memperkecil terjadinya confounding effect yang memungkinkan akan mempengaruhi perilaku data (Brown \& Warner, 1985 dalam hartono, 2005).

2. Pengujian Hipotesis 1 (Kandungan Informasi Dividen)

Untuk menguji kandungan informasi dari suatu peristiwa (pengumuman dividen) digunakan one sample t-test. Dilihat dari nilai abnormal return (AR) 5 hari sebelum dan 5 hari sesudah pengumuman dividen.

3. Pengujian Hipotesis 2 (Uji Beda ratarata dari rata-rata abnormal return Sebelum dan Sesudah Pengumuman Dividen).

Tahap-tahap pengujiannya sebagai berikut:

a. Menghitung rata-rata abnormal return seluruh saham yang dijadikan sampel sebelum dan sesudah pengumuman peristiwa. (pengumuman dividen).

b. Menghitung deviasi standart ratarata abnormal returnsebelum dan sesudah pengumuman peristiwa (pengumuman dividen).

c. Menghitung uji statistik t (ttest)pada tingkat signifikansi $\alpha=$ $5 \%$

4. Pengujian Hipotesis 3 (Uji beda Reaksi Pasar antara Perusahaan yang mengumumkan dividen naik dengan perusahaan yang mengumumkan dividen turun).

Untuk menguji hipotesis ketiga, digunakan Independen t-test.
Tahaptahap pengujiannya adalah sebagai berikut:

a. Merumuskan Hipotesis.

Ho : $\mu=0$ Ada perbedaan reaksi pasar antara perusahaan yang mengumumkan dividen naik dengan perusahaan yang mengumumkan dividen turun.

Ha : $\mu \neq 0$ Tidak ada perbedaan reaksi pasar antara perusahaan yang mengumumkan dividen naik dengan perusahaan yang mengumumkan dividen turun.

b. Menentukan taraf signifikansi $\alpha=$ $5 \%$ dengan $\mathrm{df}=\mathrm{n}-2$

c. Menentukan kriteria pengujian.

Ho diterima apabila $\mathrm{t}$ tabel $<\mathrm{t}$ hitung $<\mathrm{t}$ tabel

Ho ditolak apabila $\mathrm{t}$ hitung $>\mathrm{t}$ tabel atau t hitung $<\mathrm{t}$ tabel

d. Menarik Kesimpulan.

\section{HASIL DAN PEMBAHASAN}

Data penelitian diperoleh dari hasil analisis data melalui pengolahan statistik deskriptif. Dalam penelitian ini terdapat tiga hipotesis yang akan diuji. H1yang diajukkan adalah adanya kandungan informasi pada pengumuman dividen tunai naik dan turun. $\mathrm{H} 2$ yang diajukan adalah adanya perbedaan yang signifikan antara rata-rata abnormal return sebelum dan sesudah pengumuman dividen tunai naik dan turun. H3yang diajukan adalah adanya perbedaan reaksi pasar antara perusahaan yang mengumumkan dividen tunai naik dan perusahaan yang mengumumkan dividen tunai turun.

Hasil pengolahan statistik deskriptif yang menunjukkan data penelitian pada masing-masing variabel penelitian disajikan pada tabel 4.6 dan tabel 4.7 sebagai berikut: 
Tabel 4.6

Statistik Deskriptif Abnormal Return 5 hari sebelum, pada saat pengumuman dan 5 hari setelah pengumuman dividen tunai naik

Periode 2003-2004

Descriptive Statistics

\begin{tabular}{|c|r|r|r|r|r|}
\hline & $\mathrm{N}$ & \multicolumn{1}{|c|}{ Minimum } & Maximum & \multicolumn{1}{c|}{ Mean } & Std. Deviation \\
\hline $\mathrm{t}-5$ & 40 & -.046245 & .164101 & .00342883 & .038825673 \\
$\mathrm{t}-4$ & 40 & -.126450 & .043960 & -.007486 & .030806528 \\
$\mathrm{t}-3$ & 40 & -.107585 & .166242 & .00306963 & .042767278 \\
$\mathrm{t}-2$ & 40 & -.083661 & .125505 & .00606747 & .032129282 \\
$\mathrm{t}-1$ & 40 & -.099377 & .144311 & -.006325 & .038092292 \\
$\mathrm{t}$ & 40 & -.155995 & .337435 & -.001486 & .063542315 \\
$\mathrm{t}+1$ & 40 & -.025657 & .033968 & .00020469 & .014866646 \\
$\mathrm{t}+2$ & 40 & -.107207 & .163940 & .00439330 & .046117859 \\
$\mathrm{t}+3$ & 40 & -.169834 & .117177 & .00276869 & .042137974 \\
$\mathrm{t}+4$ & 40 & -.097540 & .072860 & .00113989 & .029346097 \\
$\mathrm{t}+5$ & 40 & -.335173 & .064251 & -.005427 & .059941736 \\
Valid N (listwise) & 40 & & & & \\
\hline
\end{tabular}

Sumber : Data Sekunder diolah 2006

Tabel 4.6 menunjukkan deskriptif statistik jumlah sampel, nilai minimum, nilai maksimum, nilai rata-rata abnormal return lima hari sebelum pengumuman, pada saat pengumuman dan lima hari setelah pengumuman dividen tunai naik. Untuk nilai minimum terbesar adalah -0.335173 jatuh pada hari ke $\mathrm{t}+5$ dan terkecil adalah 0.025657 jatuh pada hari ke $t+1$, sedangkan nilai maksimum terbesar adalah 0.337435 jatuh pada saat pengumuman dividen (t0) dan terkecil adalah 0.033968 jatuh pada hari ke $t+1$ setelah pengumuman dividen tunai naik.

Nilai standart deviasi yang digunakan untuk menunjukkan seberapa jauh nilai yang diperoleh menyimpang dari nilai yang diharapkan, standart deviasi rata-rata abnormal return disekitar tanggal pengumuman dividen tunai naik terbesar adalah 0.063542315 jatuh pada hari pengumuman dividen tunai naik ( $\mathrm{t} 0$ ) dan terkecil adalah 0.014866646 jatuh pada hari ke $\mathrm{t}+1$.

Tabel 4.7

Statistik Deskriptif Abnormal Return5 hari sebelum, pada saat pengumuman dan 5 hari setelah pengumuman dividen tunai turun Periode 2003-2004

\begin{tabular}{|c|r|r|r|r|r|}
\hline & $\mathrm{N}$ & \multicolumn{1}{|c|}{ Minimum } & Maximum & \multicolumn{1}{|c|}{ Mean } & Std. Deviation \\
\hline $\mathrm{t}-5$ & 24 & -.068866 & .075040 & -.000642 & .025551724 \\
$\mathrm{t}-4$ & 24 & -.030052 & .075040 & .00852244 & .023797560 \\
$\mathrm{t}-3$ & 24 & -.045323 & .076100 & .00335970 & .029042622 \\
$\mathrm{t}-2$ & 24 & -.075857 & .019621 & -.017919 & .021985791 \\
$\mathrm{t}-1$ & 24 & -.025657 & .091265 & .00343599 & .025567652 \\
$\mathrm{t}$ & 24 & -.496844 & .081384 & -.022887 & .104352713 \\
$\mathrm{t}+1$ & 24 & -.057190 & .062080 & .00279186 & .022088074 \\
$\mathrm{t}+2$ & 24 & -.104903 & .035149 & -.009127 & .032163490 \\
$\mathrm{t}+3$ & 24 & -.139356 & .070207 & .00097886 & .040878918 \\
$\mathrm{t}+4$ & 24 & -.047890 & .048921 & -.006537 & .020609261 \\
$\mathrm{t}+5$ & 24 & -.044015 & .082067 & .00204797 & .025404300 \\
Valid N (listwise) & 24 & & & & \\
\hline
\end{tabular}

Sumber : Data Sekunder diolah 2016 
Tabel 4.7 menunjukkan deskriptif statistik jumlah sampel, nilai minimum, nilai maksimum, nilai rata-rata abnormal return lima hari sebelum pengumuman, pada saat pengumuman dan lima hari setelah pengumuman dividen tunai naik. Untuk nilai minimum terbesar adalah -0.496844 jatuh pada hari pengumuman dividen tunai turun (to) dan terkecil adalah - 0.025657 jatuh pada hari ke $\mathrm{t}-1$, sedangkan nilai maksimum terbesar adalah 0.091265 jatuh pada hari ke t-1 dan terkecil adalah
0.019621 jatuh pada hari ke t-2 sebelum pengumuman dividen tunai turun.

Nilai standart deviasi yang digunakan untuk menunjukkan seberapa jauh nilai yang diperoleh menyimpang dari nilai yang diharapkan, standart deviasi rata-rata abnormal return disekitar tanggal pengumuman dividen tunai naik terbesar adalah 0.104352713 jatuh pada hari pengumuman dividen tunai turun $(\mathrm{t} 0)$ dan terkecil adalah 0.020609261 jatuh pada hari ke $\mathrm{t}+4$.

Tabel 4.8

Deskriptif Statistik Rata-rata abnormal return

Dividen Tunai naik dan Dividen Tunai turun

Periode 2003-2004

Descriptive Statistics

\begin{tabular}{|l|r|r|r|r|r|}
\hline & $\mathrm{N}$ & Minimum & Maximum & Mean & Std. Deviation \\
\hline AARnaik & 40 & -.028974 & .038714 & .00003176 & .011225469 \\
Valid N (listwise) & 40 & & & & \\
\hline
\end{tabular}

Descriptive Statistics

\begin{tabular}{|l|r|c|c|c|c|}
\hline & N & Minimum & Maximum & Mean & Std. Deviation \\
\hline TURUN & 24 & -.043899 & .009753 & -.003270 & .010953961 \\
Valid N (listwise) & 24 & & & \\
\hline
\end{tabular}

Sumber : Data Sekunder diolah 2006

Tabel 4.8 menunjukkan deskriptif statistik jumlah sampel, nilai minimum, nilai maksimum, nilai rata-rata abnormal return diseputar tanggal pengumuman dividen tunai naik dan pengumuman dividen tunai turun. Pada tabel 4.10 dapat dilihat rata-rata abnormal return dari dividen tunai naik dan dividen tunai turun yaitu sebesar 0.00003176 dan -0.003270 . Nilai standart deviasi digunakan untuk menunjukkan seberapa jauh nilai yang diperoleh menyimpang dari nilai yang diharapkan. Adapun standart deviasi ratarata abnormal return diseputar tanggal pengumuman dividen tunai naik dan turun adalah sebesar 0.011225469 dan 0.010953961. Untuk jumlah sampel, nilai minimum, nilai maksimum, rata-rata abnormal return dari dividen tunai naik dan dividen tunai turun selengkapnya dapat dilihat pada tabel 4.8.

\section{Hasil Pengujian Hipotesis 1}

Hipotesis pertama yang diajukkan dalam penelitian ini adalah adanya kandungan informasi pada pengumuman dividen tunai naik dan pengumuman dividen tunai turun. Pengujian kandungan informasi dimaksudkan untuk melihat reaksi dari suatu pengumuman. Reaksi ini dapat diukur dengan menggunakan abnormal return, pengumuman yang mempunyai kandungan informasi akan memberikan abnormal return kepada pasar, sebaliknya yang tidak mengandung informasi tidak memberikan abnormal return kepada pasar. Pengujian hipotesis pertama dilakukan terhadap 40 perusahaan yang mengumumkan dividen tunai naik dan 24 perusahaan yang mengumumkan dividen tunai turun. Pendekatan statistik (one sample $t$ test) digunakan untuk menguji apakah ada kandungan informasi pada pengumuman dividen tunai naik dan dividen tunai turun. Hasil pengujian 
terhadap abnormal return pada dividen tunai naik dan dividen tunai turun secara statistik dapat dilihat pada tabel 4.9 dan tabel 4.10.

Tabel 4.9

Hasil Pengujian Abnormal Return

Pengumuman dividen tunai naik

Periode 2003-2004

\begin{tabular}{|c|c|c|c|c|c|c|}
\hline \multicolumn{7}{|c|}{ One-Sample Test } \\
\hline & \multicolumn{6}{|c|}{ Test Value $=0$} \\
\hline & \multirow[b]{2}{*}{$\mathrm{t}$} & \multirow[b]{2}{*}{ df } & \multirow[b]{2}{*}{ Sig. (2-tailed) } & \multirow{2}{*}{$\begin{array}{c}\text { Mean } \\
\text { Difference }\end{array}$} & \multicolumn{2}{|c|}{$\begin{array}{l}95 \% \text { Confidence } \\
\text { Interval of the } \\
\text { Difference }\end{array}$} \\
\hline & & & & & Lower & Upper \\
\hline$t-5$ & .559 & 39 & .580 & .00342883 & -.008988 & .01584589 \\
\hline$t-4$ & -1.537 & 39 & .132 & -.00748584 & -.017338 & .00236656 \\
\hline$t-3$ & .454 & 39 & .652 & .00306963 & -.010608 & .01674727 \\
\hline$t-2$ & 1.194 & 39 & .240 & .00606747 & -.004208 & .01634292 \\
\hline$t-1$ & -1.050 & 39 & .300 & -.00632494 & -.018507 & .00585756 \\
\hline to & -.148 & 39 & .883 & -.00148578 & -.021808 & .01883604 \\
\hline$t+1$ & .087 & 39 & .931 & .00020469 & -.004550 & .00495927 \\
\hline$t+2$ & .602 & 39 & .550 & .00439330 & -.010356 & .01914251 \\
\hline$t+3$ & .416 & 39 & .680 & .00276869 & -.010708 & .01624507 \\
\hline$t+4$ & .246 & 39 & .807 & .00113989 & -.008245 & .01052523 \\
\hline$t+5$ & -.573 & 39 & .570 & -.00542656 & -.024597 & .01374374 \\
\hline
\end{tabular}

Sumber: Data sekunder diolah, 2006

Tabel 4.9 menyajikan ringkasanhasil pengujian hipotesis kandungan informasi pada pengumuman dividen tunai naik dilihat dari nilai abnormal return untuk lima hari sebelum pengumuman, pada saat pengumuman dan 5 hari setelah pengumuman dividen tunai naik.

Pengujian ini dilakukan dengan menggunakan one sampel test dengan tingkat signifikansi $(\alpha)$ sebesar 5\%. Pengujian kandungan informasi dilihat dari nilai abnormal return yang signifikan selama even period, yaitu 5 hari sebelum pengumuman sampai dengan 5 hari setelah pengumuman dividen tunai naik. Dari hasil pengujian yang dapat dilihat pada tabel 4.9, menunjukan bahwa abnormal return pada 11 hari selama even period tetapi tidak semuanya signifikan, hal ini menunjukkan bahwa pasar tidak bereaksi terhadap pengumuman kenaikan dividen tunai yang diberikan oleh pasar modal.

\section{Tabel 4.10 \\ Hasil Pengujian Abnormal Return \\ Pengumuman dividen tunai turun Periode 2003-2004}

\begin{tabular}{|c|c|c|c|c|c|c|}
\hline & \multicolumn{6}{|c|}{ Test Value $=0$} \\
\hline & \multirow[b]{2}{*}{ t } & \multirow[b]{2}{*}{ df } & \multirow[b]{2}{*}{ Sig (2-tailed) } & \multirow{2}{*}{$\begin{array}{c}\text { Mean } \\
\text { Difference }\end{array}$} & \multicolumn{2}{|c|}{$\begin{array}{l}95 \% \text { Confidence } \\
\text { Interval of the } \\
\text { Difference }\end{array}$} \\
\hline & & & & & Lower & Upper \\
\hline$t-5$ & -.123 & 23 & .903 & -.00064206 & -.011432 & .01014749 \\
\hline$t-4$ & 1.754 & 23 & .093 & .00852244 & -.001526 & .01857127 \\
\hline$t-3$ & .567 & 23 & .576 & .00335970 & -.008904 & .01562333 \\
\hline$t-2$ & -3.993 & 23 & .001 & -.01791923 & -.027203 & -.008635 \\
\hline$t-1$ & .658 & 23 & .517 & .00343599 & -.007360 & .01423226 \\
\hline to & -1.074 & 23 & .294 & -.02288668 & -.066951 & .02117760 \\
\hline$t+1$ & 619 & 23 & .542 & .00279186 & -.006535 & .01211884 \\
\hline$t+2$ & -1.390 & 23 & .178 & -.00912695 & -.022708 & .00445450 \\
\hline$t+3$ & .117 & 23 & .908 & .00097886 & -.016283 & .01824051 \\
\hline$t+4$ & -1.554 & 23 & .134 & -.00653657 & -.015239 & .00216596 \\
\hline$t+5$ & .395 & 23 & .697 & .00204797 & -.008679 & .01277526 \\
\hline
\end{tabular}

Sumber: Data sekunder diolah, 2006 
Tabel 4.10 menyajikan ringkasan hasil pengujian hipotesis kandungan informasi pada pengumuman dividen tunai turun dilihat dari nilai abnormal 5 hari sebelum pengumuman, pada saat pengumuman dan 5 hari setelah pengumuman dividen tunai turun. Pengujian ini dilakukan dengan menggunakan one sampel test dengan tingkat signifikansi $\alpha$ sebesar 5\%, pengujian kandungan informasi ini dilihat dari nilai abnormal return yang signifikan selama even period, yaitu 5 hari sebelum pengumuman sampai 5 hari setelah pengumuman dividen tunai turun. Dari hasil pengujian yang terlihat pada tabel 4.10 menunjukkan bahwa abnormal return pada 11 hari selama even period tetapi tidak semuanya signifikan.

Abnormal return ternyata muncul dengan dua arah yang berbeda yaitu negatif dan positif. Abnormal return yang signifikan pada $\alpha$ sebesar $5 \%$ muncul pada hari ke t-2 atau dua hari sebelum pengumuman dividen, sehingga dapat disimpulkan bahwa terjadi reaksi pasar signifikan pada 2 hari sebelum pengumuman dividen yang mengindikasikan bahwa adanya muatan kandungan informasi pada pengumuman dividen tunai turun.

\section{Hasil Pengujian Hipotesis 2}

Hipotesis kedua yang diajukan dalam penelitian ini adalah adanya perbedaan yang signifikan antara rata-rata abnormal return sebelum dan sesudah pengumuman dividen tunai naik dan turun. Hipotesis ini diuji dengan menggunakan paired samples $t$ test pada periode pengamatan. Hasil pengujian paired samples $t$ test untuk rata-rata abnormal return sebelum dan sesudah pengumuman dividen tunai naik dan dividen tunai turun secara ringkas disaji pada tabel 4.11 dan tabel 4.12 dibawah ini:

\section{Tabel 4.11}

\section{Hasil Uji Beda Rata-rata Abnormal Return(AAR) Sebelum dan Sesudah Pengumuman Dividen Tunai Naik Periode 2003-2004 \\ Paired Samples Test}

\begin{tabular}{|c|c|c|c|c|c|c|c|c|}
\hline & \multicolumn{5}{|c|}{ Paired Differences } & \multirow[b]{3}{*}{$\mathrm{t}$} & \multirow[b]{3}{*}{ df } & \multirow[b]{3}{*}{ Sig. (2-tailed) } \\
\hline & \multirow[b]{2}{*}{ Mean } & \multirow[b]{2}{*}{ Std. Deviation } & \multirow{2}{*}{$\begin{array}{l}\text { Std. Error } \\
\text { Mean }\end{array}$} & \multicolumn{2}{|c|}{$\begin{array}{l}95 \% \text { Confidence } \\
\text { Interval of the } \\
\text { Difference }\end{array}$} & & & \\
\hline & & & & Lower & Upper & & & \\
\hline Pair 1 AAR Sblm - Ssdh & -.000865 & .021511946 & .00340134 & -.007745 & .00601488 & -.254 & 39 & .801 \\
\hline
\end{tabular}

Sumber: Data sekunder diolah, 2006

Tabel 4.11 menyajikan ringkasan hasil pengujian hipotesis kedua dengan menggunakan paired samples $t$ test. Pada periode pengamatan sebelum dan sesudah pengumuman dividen tunai naik. Rata-rata abnormal return sebelum dan sesudah yaitu sebesar -0.000865 dengan standart deviasi sebesar 0.21511946, $\mathrm{t}$ hitung sebesar -0.254 dengan signifikansi sebesar
0.801 . Oleh karena nilai signifikansi 0.801 $>0.05$, maka hipotesis adanya perbedaan rata-rata abnormal return sebelum dan sesudah pengumuman dividen tunai naik ditolak. Dengan demikian, hipotesis yang menyatakan ada perbedaan yang signifikan antara rata-rata abnormal return sebelum dan sesudah pengumuman dividen tunai naik tidak terbukti kebenarannya. 
Tabel 4.12

Hasil Uji Beda Rata-rata Abnormal Return(AAR) Sebelum dan Sesudah Pengumuman Dividen Tunai Turun

Periode 2003-2004

Paired Samples Test

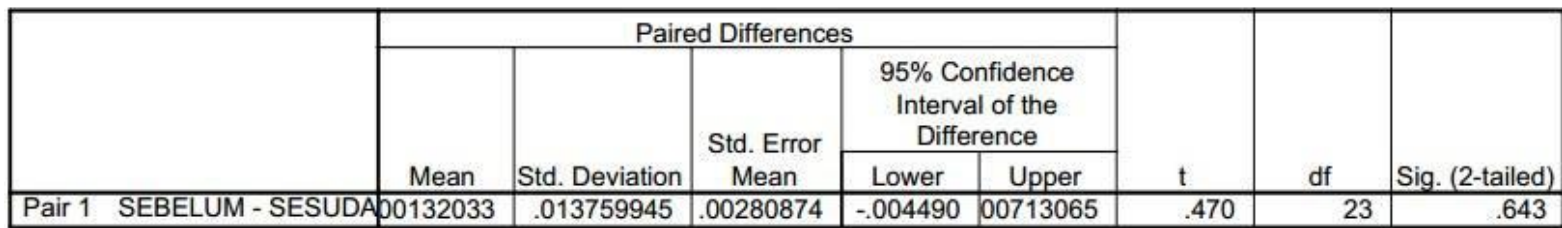

Sumber: Data sekunder diolah, 2006

Tabel 4.12 menyajikan ringkasan hasil pengujian hipotesis kedua dengan menggunakan paired samples $t$ test. Pada periode pengamatan sebelum dan sesudah pengumuman dividen tunai turun. Ratarata abnormal return sebelum dan sesudah yaitu sebesar 0.00132033 dengan standart deviasi sebesar 0.013759945 , $t$ hitung sebesar 0.470 dengan signifikansi sebesar 0,643 . Oleh karena nilai signifikansi $0,643>0.05$, maka hipotesis adanya perbedaan rata-rata abnormal return sebelum dan sesudah pengumuman dividen tunai turun ditolak. Dengan demikian, hipotesis yang menyatakan ada perbedaan yang signifikan antara rata-rata abnormal return sebelum dan sesudah pengumuman dividen tunai turun tidak terbukti kebenarannya.

\section{Hasil Pengujian Hipotesis 3}

Hipotesis ketiga yang diajukan dalam penelitian ini adalah adanya perbedaan reaksi pasar yang signifikan antara perusahaan yang mengumumkan dividen tunai naik dan perusahaan yang mengumumkan dividen tunai turun. Hipotesis ini akan diuji dengan menggunakan Independent Samples Test. Hasil pengujian Independent Samples test untuk perusahaan yang mengumumkan dividen tunai naik dan perusahaan yang mengumumkan dividen tunai turun dilihat dari nilai rata-rata abnormal return nya (AAR) secara ringkas disajikan pada tabel 4.13 dibawah ini:

Tabel 4.13

Hasil Independent Samples Test AAR Dividen Naik dan Dividen Turun

\begin{tabular}{|c|c|c|c|c|c|c|c|c|c|c|}
\hline \multicolumn{11}{|c|}{ Independent Samples Test } \\
\hline & & \multicolumn{2}{|c|}{$\begin{array}{l}\text { Levene's Test for } \\
\text { Equality of Variances }\end{array}$} & \multicolumn{7}{|c|}{ t-test for Equality of Means } \\
\hline & & \multirow[b]{2}{*}{$\mathrm{F}$} & \multirow[b]{2}{*}{ Sig. } & \multirow[b]{2}{*}{$\mathrm{t}$} & \multirow[b]{2}{*}{ df } & \multirow[b]{2}{*}{ Sig. (2-tailed) } & \multirow{2}{*}{$\begin{array}{c}\text { Mean } \\
\text { Difference }\end{array}$} & \multirow{2}{*}{$\begin{array}{l}\text { Std. Error } \\
\text { Difference }\end{array}$} & \multicolumn{2}{|c|}{$\begin{array}{l}\text { 95\% Confidence Interval } \\
\text { of the Difference }\end{array}$} \\
\hline & & & & & & & & & Lower & Upper \\
\hline AAR & $\begin{array}{l}\text { Equal variances } \\
\text { assumed }\end{array}$ & .007 & .933 & 1.150 & 62 & .255 & .00330219 & .00287260 & -.0024401 & .00904443 \\
\hline
\end{tabular}

Sumber: Data sekunder diolah, 2006

Hasil pengujian Independent Samples Test untuk menguji apakah terdapat perbedaan reaksi pasar antara perusahaan yang mengumumkan kenaikan dividen dengan perusahaan yang mengumumkan penurunan dividen. Pada Levene's Test menunjukkan bahwa $\mathrm{F}$ hitung untuk AAR signifikan pada $\alpha=5 \%$ (sig. $=0,933>0,05)$ sehingga kedua kelompok memiliki varian yang sama. Pada tabel didapat nilai $t$ hitung menunjukkan probabilitas sebesar 0,255 Oleh karena nilai probabilitas 0,255 $>0.05$, maka hipotesis yang menyatakan adanya perbedaan reaksi pasar antara 
perusahaan yang mengumumkan kenaikan dividen dengan perusahaan yang mengumumkan penurunan dividen tunai ditolak, dan tidak terbukti kebenarannya.

\section{Pembahasan}

Penelitian ini mencoba untuk menganalisis kandungan informasi dari pengumuman dividen tunai naik dan turun, menganalisis perbedaan ratarata abnormal returnsebelum dan sesudah pengumuman dividen baik naik maupun turun, serta menganalisis perbedaan reaksi pasar antara perusahaan yang mengumumkan dividen tunai naik dengan perusahaan yang mengumumkan dividen tunai turun yang listeddan terdaftar di BEJ periode 20032004.

Reaksi pasar dilihat dari nilai ratarata abnormal return pada periode pengamatan. Berdasarkan analisis yang dilakukan, untuk menguji kandungan informasi dari pengumuman dividen tunai naik dan turun, sampel yang digunakan sebanyak 40 perusahaan yang mengumumkan dividen tunai naik dan 24 perusahaan yang mengumumkan dividen tunai turun pada periode tahun tersebut. Hasil yang didapat adalah pasar tidak bereaksi terhadap pengumuman kenaikan dividen, ini dikarenakan karena muatan informasi kenaikan dividen tunai tidak bermakna bagi pasar. Hasil ini konsisten dengan penelitian yang dilakukan oleh Gonedes (1978), Brooks (1996), Amsari (1993), Soetjipto (1997) dan Rahardjo (2000). Pada pengumuman dividen tunai turun pasar bereaksi negatif signifikan pada hari ke t-2 atau dua hari sebelum dividen tunai turun diumumkan, terjadinya reaksi pasar sebelum tanggal pengumuman menunjukkan adanya kebocoran informasi yang diterima oleh pelaku pasar sebelum pengumuman dividen dikeluarkan. Kebocoran informasi ini bisa terjadi karena sebagian investor memperoleh akses informasi ke dalam perusahaan atau mereka mempunyai akses privat terhadap informasi dan menggunakannya untuk melakukan transaksi, sehingga hal ini mengindikasikan adanya kandungan informasi pada pengumuman dividen tunai turun. Temuan penelitian ini mendukung hipotesis kandungan informasi pengumuman dividen yang menyatakan bahwa pengumuman dividen mengandung informasi yang berguna bagi investor. Hasil ini konsisten dengan penelitian yang dilakukan oleh Petit (1972), Aharony \& Swary (1980), Benartzi et al (1997), Mikhail et al(1999), Sujoko (1999), Suparmono (2000), Setiawan \& Hartono (2003) dan Yusnitasari (2003).

Pengujian terhadap perbedaan antara rata-rata abnormal return sebelum dan sesudah pengumuman dividen tunai naik dan turun pada periode pengamatan. Berdasarkan analisis yang dilakukan dengan menggunakan Paired Samples Test terhadap AAR, hasil yang diperoleh adalah tidak ada perbedaan antara rata-rata abnormal returnsebelum dan sesudah pengumuman dividen tunai naik dan turun dilihat dari nilai signifikansi untuk dividen naik sebesar $0.801>0.05$ dan dividen turun sebesar $0.643>0.05$. Dengan demikian, hipotesis yang menyatakan ada perbedaan secara signifikan antara ratarata abnormal return sebelum dan sesudah pengumuman dividen tunai naik dan turun tidak terbukti kebenarannya, kenyataan ini mengindikasikan banyaknya informasi lain diluar informasi naik turunnya dividen tunai yang dibagikan dan mempengaruhi pergerakan harga saham baik sebelum maupun sesudah pengumuman dividen tunai naik dan turun, sehingga variabilitas return yang terjadi antara sebelum dan sesudah pengumuman dividen tidak berbeda secara nyata. Hasil ini konsisten dengan penelitian yang dilakukan oleh Prasetiono (2000).

Pengujian terhadap perbedaan reaksi pasar antara perusahaan yang melakukan pengumuman dividen tunai naik turun, sampel dikelompokkan menjadi 2 kelompok, yaitu perusahaan yang melakukan pengumuman dividen naik sebesar 40 perusahaan dan perusahaan yang melakukan pengumuman dividen tunai turun sebanyak 24 perusahaan. 
Berdasarkan analisis yang dilakukan dengan menggunakan Independent Samples Test terhadap nilai AAR, hipotesis ketiga (H3) ditolak, dilihat dari nilai signifikansi sebesar $0.255>0.05$ artinya tidak ada perbedaan reaksi pasar antara perusahaan yang mengumumkan dividen tunai naik dan turun.

\section{Kesimpulan}

Secara umum penelitian ini bertujuan untuk menganalisis apakah pengumuman dividen memiliki kandungan informasi atau tidak untuk perusahaan yang mengumumkan dividen tunai naik dan turun yang listeddan terdaftar di Bursa Efek Jakarta Periode 2003-2004, menganalisis perbedaan rata-rata abnormal return sebelum dan sesudah pengumuman dividen tunai naik dan turun, serta menganalisis perbedaan reaksi pasar antara perusahaan yang mengumumkan dividen tunai naik dengan perusahaan yang mengumumkan dividen tunai turun.

Penelitian ini menyimpulkan bahwa:

a. Terbukti bahwa terdapat kandungan informasi pada pengumuman dividen tunai turun dilihat dari nilai abnormal return yang signifikan 2 hari sebelum pengumuman dividen tunai turun, sedangkan untuk pengumuman dividen naik tidak ada nilai dari abnormal return yang signifikan, artinya bahwa tidak ada kandungan informasi pada pengumuman dividen tunai naik untuk periode 2003-2004.

b. Tidak terdapat perbedaan yang signifikan antara rata-rata abnormal return sebelum dan sesudah pengumuman dividen tunai naik dan turun untuk periode 2003-2004.

c. Tidak terdapat perbedaan reaksi pasar antara perusahaan yang melakukan pengumuman dividen tunai naik dan turun periode 2003-2004.

\section{Daftar Referensi}

Aharony, Joseph dan Itzhak Swary. 1980. "Quarterly Dividends and Earnings Announcement and Stocholders'Return: An Empirical Analysis", The Journal of Finance 35 (Maret): 1-12.

Amsari, M. Ishak. 1993. Pengaruh Pengumuman Dividen terhadap Harga Saham di Pasar Modal Indonesia. Tesis S2. Universitas Gadjah Mada, Yogyakarta.

Benartzi, Shlomo, Roni Michaely dan Richard H. Thealer. 1997. "Do Changes in Dividend Signal the Future or The Past", The Journal of Finance 52 (Juli) 10071034.

Brickley, James A. 1983. "Shareholder Wealth, Information Signaling and the Specially Designated Dividend", Journal of Financial Economics 12 (Juni):1987209.

Fama, Eugene F. 1970. "Efficient Capital Market: A Review of Theory and Empirical Work", The Journal of Finance 25:383-417.

Gelb, David S. 1999. "Corporate Signalling with Dividend, StockRepurchase, and Accounting Disclosure: An Empirical Study". Journal of Accounting, Auditing \& Finance: 99120.

Gombola, Michael J. dan Feng Ying Liu. 1999. "The Signalling Power of Specially Designated Dividend". Journal of Finance and Quantitative Analysis34 (September): 409-424

Gunawan, Barbara. 2004. "Analisis Efisiensi Pasar Modal 'Semistrong Form Test' dengan adanya pengumuman right issue di Bursa Efek Jakarta". Jurnal Akuntansi dan Investasi Vol 5 (2) Juli. 
Hartono, Jogiyanto. $1998 . \quad$ "Teori Portofolio dan Analisis Investasi”.Yogyakarta: BPFE Universitas Gajah Mada.

2000. Teori Portofolio dan Analisis Investasi, Edisi Kedua. Yogyakarta: BPFE Universitas Gajah Mada.

Soetjipto, Kery. 1997. "Pengaruh Pengumuman Dividen terhadap Kandungan Informasi Pengumuman Laba". Tesis S2. UGM, Yogyakarta.

Sujoko. 1999. "Analisis Kandungan Informasi dan Ketepatan Reaksi Pasar: Pengujian terhadap Dividend Signalling Theory Studi Empiris di Bursa Efek Jakarta". Tesis S2. UGM, Yogyakarta.

Suparmono. 2000. "Dividend Announcement Effects on Stock Return: A Test of Signalling Hyphotesis in the Indonesian Stock Market". Gajah Mada International Journal of Business 2 (September):351-368.

Yusnitasari, Emilia F. 2003. "Transfer Intra Industri di Sekitar Pengumuman Dividen". Jurnal Riset Akuntansi Indonesia, 6 (Mei):145-168 